музикування, удосконалення навчально-методичного забезпечення з концертмейстерського класу.

\section{СПИСОК ВИКОРИСТАНОЇ ЛІТЕРАТУРИ}

Хлопова, А. А., Опанасенко, О. О., Олейніков, С. О. (2017). Роль та специфіка акомпанементу у процесі виховання естрадних вокалістів. Актуальні аспекти сучасного українського музичного мистецтва: колективна монографія / за ред. В. В. Синельникової, А. Б. Попової. Київ: Ліра. С. 104-109.

Несмашна, Л. Ю., Сарбі, С. С., Бокоч, В. А. (2017). Концертмейстер у вокально-фортепіанному дуеті: специфіка співтворчості. Актуальні аспекти сучасного украӥнського музичного мистецтва: колективна монографія / за ред. В. В. Синельникової, А. Б. Попової. Київ: Ліра. С. 110-119.

Молчанова, Т. О. (2001). Мистецтво піаніста-концертмейстера. Львів: ДМА. 216 с.

Афанасьєва, Е. Ю. (2017). Педагогічний підхід концертмейстера в роботі з студентами-музикантами. Музичне мистецтво Украӥни: монографія / за ред. Н. М. Кречка. Київ: Ліра. С. 38-45.

УДК 78:615.86

DOI: 10.37026/2520-6427-2021-106-2-164-168

\section{REFERENCES}

Khlopova, A. A., Opanasenko, O. O., Oleinikov, S. O. (2017). Rol ta spetsyfika akompanementu u protsesi vykhovannia estradnykh vokalistiv [The role and specifics of accompaniment in the process of educating pop vocalists]. Aktualni aspekty suchasnoho ukrainskoho muzychnoho mystetstva: kolektyvna monohrafiia / za red. V. V. Synelnykovoi, A. B. Popovoi. Kyiv: Lira. S. 104-109. [in Ukrainian].

Nesmashna, L. Iu., Sarbi, S. S., Bokoch, V. A. (2017). Kontsertmeister u vokalno-fortepiannomu dueti: spetsyfika spivtvorchosti [Concertmaster in a vocal-piano duo: the specifics of co-creation]. Aktualni aspekty suchasnoho ukrainskoho muzychnoho mystetstva: kolektyvna monohrafiia / za red. V. V. Synelnykovoi, A. B. Popovoi. Kyiv: Lira. S. 110-119. [in Ukrainian].

Molchanova, T. O. (2001). Mystetstvo pianistakontsertmeistera [The art of a pianist-accompanist]. Lviv: DMA. 216 s. [in Ukrainian].

Afanasieva, E. Iu. (2017). Pedahohichnyi pidkhid kontsertmeistera $\mathrm{v}$ roboti $\mathrm{z}$ studentamy-muzykantamy [Pedagogical approach of the accompanist in work with students-musicians]. Muzychne mystetstvo Ukrainy: monohrafiia / za red. N. M. Krechka. Kyiv: Lira. S. 38-45. [in Ukrainian].

Дата надходження до редакиіï: 02.03.2021 p.

\author{
Михайло КРЕТ, \\ кандидат педагогічних наук, доцент \\ кафедри пісенно-хорової практики \\ та постановки голосу \\ Інституту мистеитв \\ Рівненського державного \\ гуманітарного університету, \\ м. Рівне, Україна \\ ORCID: 0000-0002-0052-1194 \\ e-mail:9842424@gmail.com \\ Наталія ЛЕВЧУК, \\ студентка магістратури \\ кафедри естрадної музики \\ Інституту мистеитв \\ Рівненського державного \\ гуманітарного університету, \\ м. Рівне, Украӥна \\ ORCID: 0000-0003-2479-9286 \\ e-mail:krolowanataliia@gmail.com
}

\title{
МУЗИКОТЕРАПІЯ ЯК ЧИННИК ВПЛИВУ НА ПСИХОЕМОЦЙНИЙ СТАН ОСОБИСТОСТІ
}

Анотація. Стаття присвячена вивченню музикотерапї як оздоровчо-розвивального підходу до покращення психоемоиійного стану особистості.

Визначено, що музикотерапія - це системне використання музики з метою лікування фізіологічних та психосоиіальних аспектів хвороби та різноманітних розладів. Доведена актуальність музики та схарактеризовані ії иүілющі властивості ще з глибокої давнини. Окреслені погляди сучасних учених на музикотерапію та ї̈ вплив на лікування і профілактику багатьох захворювань.

Доведено, шео музикотерапія позитивно впливає на становлення й розвиток гармонійної особистості через вплив на емочійно-почуттєву сферу, психофізіологічний стан. Встановлено, що зміни, які відбуваються в психічному розвитку індивідуума, можуть бути коригованими та вмотивованими музично- 
терапевтичними засобами з метою досягнення лікувальних результатів. Схарактеризоване значення властивостей класичної музики.

У контексті дослідження музично-терапевтичного впливу представлено добірку музичних творів, щчо сприяють оздоровленню та гармонізаиії психоемочійного стану особистості.

Ключові слова: музикотерапія, психоемоційний стан, особистість, музика, здоров'я.

\author{
Mykhaylo KRET, \\ Candidate of Pedagogical Sciences, \\ Associate Professor, \\ Department of song, \\ Choral practice and \\ Voice staging of the Institute of Arts, \\ Rivne State University for the Humanities, \\ Rivne, Ukraine \\ ORCID: 0000-0002-0052-1194 \\ e-mail:98424242@gmail.com

\section{Natalia LEVCHUK,} \\ Student of the second (master's) level, \\ Department of pop music of the Institute of Arts, \\ Rivne State University for the Humanities, \\ Rivne, Ukraine \\ ORCID: 0000-0003-2479-9286 \\ e-mail:krolowanataliia@gmail.com
}

\section{MUSIC THERAPY AS A FACTOR OF INFLUENCE ON PSYCHO-EMOTIONAL STATE OF A PERSONALITY}

\begin{abstract}
The article is dedicated to studying music therapy as health and developing approach to improving psycho-emotional personality's state.

Music therapy is a systemic using of music for treatment psychological and psycho-social aspects of a disease or disorders. Music can generate psychic and somatic processes in a human organism. When a person fills internally hearing a piece of music, certain associations appear and mood with emotions are being changed. Music influences on vegetative processes - activity of internal organs and systems, metabolism and functional state of a body.

Thus, music as a psychophysiological irritant combine's ability for complex, diversified in power and direction influence on a personality. Despite the civilization process music has not lost its power to cause positive action on a personality, but vice versa emphasized its music-therapeutic possibilities which are able to protect a person from stress situations.

It has been proved that healing properties of music and its actuality since deep antiquity up to nowadays. It is defined that from many various viewpoints on music therapy and its influence on treatment and disease prevention scientists from many countries in more details pay attention to this problem.

It is well known that music therapy positively influences on formation and development of harmonious personality through the influence on emotional and sensual sphere, psychophysiological state. It is established that changes which happen in psychical development of an individual can be adjusted and motivated by music therapeutic means for achieving medical results. The importance of healing properties of classic music has been characterized.
\end{abstract}

In $X X^{\text {th }}$ century music therapy attained a considerable significance in a society. After examining music mentality of Ukrainian nation we have come to the conclusions that more detailed studying of the problem by in Ukrainian researchers is needed.

In the contest of music-therapeutic influence selection of musical works with the purpose to recover and harmony psycho-emotional state of a personality has been presented.

Key words: music therapy, psycho-emotional state, personality, music, health.

Постановка проблеми. У сучасному суспільстві проблема збереження та відновлення психоемоційного стану особистості є досить актуальною, адже більшість негативних факторів сьогодення призводять до певної неефективності фізичної діяльності та погіршення загального стану здоров'я. Крім того, сьогодні в Україні спостерігається значне інтелектуальне, емоційне й психологічне навантаження на дитину, що спричиняє стрес, поганий настрій та дратівливість. Як наслідок - виникає потреба у пошуку нових методів впливу на ментальний, психічний та фізичний рівень здоров'я підростаючого покоління, що за нинішніх умов набуває особливої актуальності. Водночас варто відзначити, що означена проблематика актуальна не лише з позиції наукового обгрунтування, а й із погляду іiі практичного впровадження в життя.

Зважаючи на зазначене вище, звернення до музикотерапії як одного із методів оздоровчої практики психоемоційного стану є досить важливим, адже стосується умов покращення духовного розвитку та здорового способу життя особистості. 
Аналіз наукових досліджень і публікацій. Icнує значна кількість публікацій вітчизняних і зарубіжних науковців у галузі музикотерапії. Так, питання впливу музики на організм, інтелектуальну діяльність та душевний стан людини розкривають у своїх працях В. Бехтерєв, С. Хміль, І. Шабутіна, С. Науменко, Т. Яковенко, І. Малашевська. Заслуговують на особливу увагу дослідження в означеному напрямі Г. Апанасенко, О. Клюєва, В. Петрушина, Г. Побережної, Т. Львова, Д. Кемпбел, Н. Яновської та інших учених. Науково-практичний досвід щодо специфіки застосування принципів і методів музикотерапії з метою моделювання психоемоційних станів аналізується у працях О. Блінової, Л. Брусиловського, М. Обозова, К. Швабе, Г. Побережної, Т. Ткаченко та ін.

Метою статті $\epsilon$ дослідження терапевтичного впливу музичного мистецтва на психоемоційний стан особистості.

Виклад основного матеріалу дослідження. 3 усіх видів мистецтва музика має найбільший вплив на психіку людини, іiі настрій, функціональну активність та працездатність, а також на ії духовний світ (Малашевська, 2017, с. 101).

Музикотерапія - це психотерапевтичний метод впливу музики на психіку людини. Однак одна й та ж музика здатна впливати на особистість як позитивно, так і негативно, адже фізіологічна та емоційна реакція слухача на неї залежить від багатьох індивідуальних чинників, зокрема: музичні вподобання, настрій, характер, емоційний стан, досвід слухача, соціальний статус тощо. Доведено, що музика завдяки своїй здатності впливати на внутрішній світ людини відіграє особливу роль у налагодженні особистого дискомфорту, коректує емоційний стан, допомагає звільнитися від негативних емоцій, активізує розумові здібності, розвиває та підвищує інтелект, позитивно впливає на загальний стан здоров'я людини.

Термін «музикотерапія» греко-латинського походження і в перекладі означає «зцілення музикою». Ще 3 найдавніших часів відомі цілющі властивості музики, що знайшли своє відображення у стародавніх міфах, філософсько-естетичних поглядах і трактатах. Музика була частиною «магічних», релігійних та оздоровлювальних ритуалів і слугувала 3 метою відганяння злих духів, хвороби чи смерті, а також слугувала засобом керування стихіями природи. Стародавні мудреці вважали, що музика та іiї перший звук народилися одночасно iз творінням світу. У 1889 році англійський археолог Фліндерс Пітрі знайшов єгипетські папіруси, датовані 1500 роком до н.е., в яких згадується про вплив музики на людське тіло. Сгиптяни зцілювали музикою душевнохворих, використовуючи плавання на човнах по Нілу під супровід гри на музичних інструментах (Сливка, 2015).

Вважалося, що музика та співи сприяли зціленню людини, а тому були поширеними серед представників релігійно-містичної медицини. Усі найдавніші вчення земних цивілізацій містять у собі подібні твердження і досвід впливу музики на тварин, рослин та людей. Давньогрецький математик та мислитель Піфагор у 590500 роках до н. е. заснував науку про гармонію сфер i визначив музику як точну науку, використовуючи ії в лікувальних цілях, а його послідовники-піфагорійці проводили під музику заняття з математики. Аристотель вважав, що музика дозволяє уникнути важких психологічних хвилювань, у зв'язку з чим розробив учення щодо впливу мистецтва на внутрішній світ людини. Завдяки цій теорії мислитель започаткував концепцію катарсису, згідно з якою в душі слухача і глядача грецької трагедії відбувалося очищення від хворобливих афектів.

У Стародавньому Китаї ієрогліф, який символізував музику, позначав також радість і благополуччя. Китайці вбачали суть музикотерапії в тому, що вона повинна об'єднати розум, тіло і дух людини. Конфуцій грав на цині (китайський музичний інструмент), Гіпократ волів лікувати істерію грою на флейті, Авіценна називав мелодію «нелікарським» методом лікування поряд 3 дієтою, запахами і сміхом та присвятив цілий розділ зв'язку мелодії і пульсу у своїй «Книзі зцілення» (Ткаченко, 2012).

Містична література іудаїзму, християнства, icламу і гностицизму окреслює музику як засіб божественного порядку та чарівності. У середньовічній Свропі мистецтво музики трактувалося насамперед як метод морально-релігійного виховання. Зокрема, один із теологів епохи Відродження і Нового часу М. Лютер відзначав, що музика після теології здатна дати те, що дає теологія, тобто спокій і радість душі (Апанасенко, Савельева-Кулик, 2011).

На думку дослідників, перші спроби пояснення впливу музики на фізіологічний і психічний стан людини сягають XVII ст. У цей період з'явилося чимало праць, у яких описується вплив на людину певних ладів, ритмів, музичних форм тощо. Починаючи з XIX ст. завдяки науковим дослідженням також отримано чимало важливих відомостей у цій галузі. Так, було доведено, що музика здатна впливати на систему дихання, серцевий ритм, пульс і тиск. Російсько-грузинський фізіолог Іван Тарханов зазначав, що мелодія, яка подобається людині, може знижувати артеріальний тиск, а музика, що не до вподоби, здатна викликати протилежний ефект. Такої ж думки дотримувався американський лікар-невропатолог Дж. Корнінг. Досліджуючи оздоровчий вплив музики на організм людини під час лікування психічних розладів, він застосовував твори Вагнера, виконання яких давало доволі позитивний результат. Російський психіатр, невропатолог, фізіолог, академік В. Бехтерєв вивчав вплив музики на дихання, кровообіг, зменшення фізичного навантаження, усунення втоми. На його думку, з метою «переведення дитини із сумного стану у мажорний необхідно спочатку затримати іiї у цьому стані сумною піснею, а згодом поступово перевести в оптимістичний стан ритмічною мажорною піснею» (Сливка, 2015).

Музикант і лікар Патрік Єшвен, автор книги «Музика і медицина», досліджуючи вплив музики на людину, зазначав, що з-поміж усіх видів мистецтва музика $€$ «найбільш безболісним лікувальним засобом» (Використання музичного мистецтва як засобу терапії, 2021).

У 1918 році розробником музичної терапії як навчальної дисципліни став музикант із Великої Британії М. Андерсен. Загалом у ХХ ст. у США, країнах Європи та в Росії музикотерапія стає професійною спеціалізацією. 
3'являються нові школи цього напряму, зокрема шведська, німецька, французька, італійська, представниками яких були А. Понтвік, Б. Швабе, С. Кенінг, А. Томатіс, А Менегетті, В. Бехтерєв, І. Сєченов (Малашевська, 2017, с.104; Апанасенко, Савельева-Кулик, 2011).

В Україні музикотерапія як окрема наукова галузь досі залишається недостатньо вивченою. Заслуговують на увагу в означеному напрямі навчальні посібники сучасного молодого науковця В. Драганчук, зокрема «Музична терапія: теорія та історія» (2010) і «Музична психологія і терапія» (2016), в яких авторка розкриває музикознавчі основи застосування музики у терапевтичних цілях.

Варто відзначити, що сьогодні серед науковців не існує єдиної думки щодо лікувальних властивостей музики, хоча більшість лікарів-психотерапевтів доводять, що в основі цієї теорії - здатність музики впливати на психоемоційний стан особистості. Психосоматична медицина підтримує твердження, що більшість хвороб спричинена психологічними невідповідностями і розладами, що виникають у людській підсвідомості, думках. У зв'язку з цим лікування таких захворювань залежить від людини та іії ставлення до навколишнього світу і важливу роль за цієї умови відіграє саме музика як один із основних інструментів лікувального впливу.

Порівнюючи музикотерапію 3 швидкою допомогою, ми вважаємо, що вона здатна вивести людину навіть із депресивного стану. Емоційне потрясіння і співпереживання, що виникають, коли прослуховуються певні музичні твори, можуть сприяти душевному спокою слухача. До таких видів музики належить, зокрема, класична музика, особливо у «живому виконанні», в основі якої - віковий художній досвід, життєва мудрість, надбання різних історичних епох.

Психологічні механізми, що є основою особистісних змін, передбачають ідентифікацію із художнім образом музичного твору, співпереживання емоційних станів, рефлексію та співвідношення власного життєвого досвіду з життєвим досвідом автора музичного твору, що відображається за допомогою музики.

Дослідження доводять, що під час прослуховування музичних творів слухач переживає «бурю» емоцій, котрі сприяють зняттю стресу, дратівливості, афектних станів тощо. Вважається, що такими властивостями наділена «Місячна соната» Л. Бетховена, «Симфонія» Й. Гайдна, «Італійський концерт» I. Баха, «Прелюдія мі мінор №4» Ф. Шопена. Приміром, від неврозів допомагає музика П. Чайковського - «Лускунчик», увертюри «Ромео і Джульєта»; від мігрені - «Весняна пісня» Ф. Мендельсона, «Американець у Парижі» Дж. Гершвіна; нормалізує сон сюїта «Пер Гюнт» Е. Гріга, «Сумний вальс І. Сибеліуса, «Марення» Р. Шумана, «Wof Rain» Я. Нікітіна і С. Кузнецова, головний біль знімає «Полонез» М. Огінського.

Для того, щоб позбутися відчуття самотності, невпевненості, тривоги, закомплексованості, варто зробити акцент на прослуховуванні інструментальних творів Ф. Шопена - прелюдії, мазурки, колискові та ноктюрни, Ф. Шуберта - «Аве Марія», Й. Брамса «Колисанка», К. Дебюсі - «Світло місяця». Особливу увагу варто приділити музиці В. Моцарта, яка найбільш незвичайна у своїй простоті, адже є не швидкою, але й не повільною, плавною, однак водночас не набридливою. Цей феномен учені називають «ефектом Моцарта» (Використання музичного мистецтва як засобу терапії, 2021; Ткаченко, 2012).

Водночас варто відзначити, що музика не завжди здатна позитивно впливати на організм людини. Так, сучасна «молодіжна» музика (рок, реп, поп тощо) досить часто має негативний вплив на емоційну сферу особистості. Такі жанрові композиції у поєднанні 3 мерехтливими зображеннями та гучним ритмічним виконанням здатні викликати агресивність, роздратованість і відчуття тривоги. Зважаючи на це, для музикотерапії найбільш характерною є класична музика, а також народні мелодії.

На сучасному етапі музика використовується не лише під час занять 3 музичної терапії, а й як метод всебічної та багатоаспектної стимуляції розвитку. Психологи стверджують, що саме рухи та спів, що виражають музичну експресію, $є$ елементом природної активності дітей і дозволяють їм бути успішними (Музична терапія в розвитку дитини, 2021).

Доведено, що під впливом правильно підібраної музики позитивно формуються психічні процеси дитини (сприйняття, мислення, пам'ять, уява), загальна і дрібна моторика, координація, стає виразнішою мова, 3'являються перші навички спілкування (Куцин, 2019). У зв'язку з цим заняття музикою активізує у дітей розумовий процес, вимагає концентрації уваги, спостережливості, кмітливості, стимулює загальний розвиток дитини, сприяє формуванню особистості загалом.

На думку дослідників у галузі медицини, психології та педагогіки, музична терапія здатна моделювати складні процеси духовного і фізичного розвитку особистості на рівні свідомості й підсвідомості, а також забезпечує основу емоційного контакту між дорослим і дитиною. Існує твердження, що будучи ще в материнській утробі, дитина відчуває музику, ритм материнського серця, тональність і1ї голосу. Це сприяє кращому обміну речовин, зміцнює дихання, посилює або зменшує м'язову енергію. Жінка, яка носить у собі майбутнє життя і слухає музику, допомагає дитині краще пізнати навколишній світ, що позитивно впливає на відповідні психічні процеси.

Висновки. Отже, музика є універсальним механізмом, що діє на особистість комплексно незалежно від iіi віку та дозволяє розблокувати емоції без допомоги лікаря чи психолога (Музична терапія, 2021). Проаналізувавши низку психолого-педагогічних розвідок, присвячених музикотерапії, ми дійшли висновку, що означена дисципліна має здатність впливати і коригувати психоемоційний стан особистості. Володіючи потужним потенціалом, музикотерапія потребує глибшого застосовування в сучасних умовах, адже спостерігається посилення інформаційного впливу на дітей, фізично-емоційні та розумові перевантаження, прискорення темпу життя загалом (Малашевська, 2017, c. 135). Крім того, музикотерапія має певні переваги порівняно з іншими методами лікування, оскільки не викликає побічних ефектів та звикання.

Перспективи подальших досліджень убачаємо в подальшому вивченні музикотерапії як нового методу лікування хвороб і профілактики різноманітних захворювань. 


\section{СПИСОК ВИКОРИСТАНОЇ ЛІТЕРАТУРИ}

Малашевська, I. А. (2017). Теорія і практика навчання музики дітей дошкільного та молодшого шкільного віку з використанням музикотерапії: дис. ... доктора пед. наук / Київський національний педагогічний ун-т ім. М. Драгоманова. Київ. 455 с.

Сливка, Л. В. (2015). Музикотерапія в освітньому процесі: історичне і теоретичне підгрунтя. URL: https:// dspace.uzhnu.edu.ua/jspui/bitstream/lib/10504/1/M (дата звернення: 05.05.2021).

Ткаченко, Т. В. (2012). Музикотерапія і її внесок в оздоровчу, виховну і моральну функцію молоді. URL: http://file://c:/Users/Admin/Downloads/ Mir_2012_4_6\%20(1).pdf (дата звернення: 06.05.2021).

Апанасенко, Г. Л., Савельева-Кулик, Н. А. Музыкальная терапия: история, современность и перспективы развития. Украӥнський медичний часопис. Київ. № 4 (90-У11/У111). С. 170-173.

Використання музичного мистецтва як засобу терапії. (2021). URL: http://osvita.ua/vnz/reports/ culture/11655/ (дата звернення: 07.05.2021).

Драганчук, В. М. (2010). Музична терапія: теорія та історія. Луцьк: РВВ «Вежа» Волинського національного ун-ту ім. Лесі Українки. 225 с.

Драганчук, В. М. (2016). Музична психологія і терапія. Луцьк: Східноєвропейський національний ун-т ім. Лесі Українки. 230 с.

Музична терапія в розвитку дитини. (2021). URL: https://childdevelop.com.ua/articles/develop/130/ (дата звернення: 05.05.2021).

Куцин, Е. К. (2019). Формування основи розвитку особистості засобами творчої музичної діяльності. URL: http://visnyk.chnpu.edu.ua $>$ uploads $>2020 / 05>$ Kutsyn. pdf (дата звернення: 11.05.2021).

\section{REFERENCES}

Malashevska, I. A. (2017). Teoriia i praktyka navchannia muzyky ditei doshkilnoho ta molodshoho shkilnoho viku z vykorystanniam muzykoterapii [Theory and practice of teaching preschool children music using music therapy]: dys. ... doktora ped. nauk / Kyivskyi natsionalnyi pedahohichnyi un-t im. M. Drahomanova. Kyiv. 455 s. [in Ukrainian].
Slyvka, L. V. (2015). Muzykoterapiia v osvitnomu protsesi: istorychne i teoretychne pidgruntia [Music therapy in educational process: historical and theoretical underground]. URL: https://dspace.uzhnu.edu.ua/jspui/bitstream/lib/10504/1/M (data zvernennia: 05.05.2021). [in Ukrainian].

Tkachenko, T. V. (2012). Muzykoterapiia i yii vnesok v ozdorovchu, vykhovnu i moralnu funktsii u molodi [Music therapy and its contribution to health, educational and moral functions of youth]. URL: http://file:///c:/Users/Admin/Downloads/Mir_2012_4_6\%20(1).pdf (data zvernennia: 06.05.2021). [in Ukrainian].

Apanasenko, G. L., Saveleva-Kulik, N. A. Muzyikalnaya terapiya: istoriya, sovremennost i perspektivyi razvitiya [Musictherapy: history, modernity and development prospects]. Ukrayinskiy medichniy chasopys. Kyiv. № 4 (90-U11/U111). S.170-173. [in Russian].

Vykorystannia muzychnoho mystetstva yak zasobu terapii [Using music art as means of therapy]. (2021). URL: http://osvita.ua/vnz/reports/culture/11655/ (data zvernennia: 07.05.2021). [in Ukrainian].

Drahanchuk, V. M. (2010). Muzychna terapiia: teoriia ta istoriia. Lutsk: RVV «Vezha» Volynskoho natsionalnoho un-tuim. Lesi Ukrainky. 225 s. [in Ukrainian].

Drahanchuk, V. M. (2016). Muzychna psykholohiia i terapiia [Music psychology and therapy]. Lutsk: Skhidnoi evropeiskyi natsionalnyi un-t im. Lesi Ukrainky. $230 \mathrm{~s}$. [in Ukrainian].

Muzychna terapiia v rozvytku dytyny [Music therapy in a child development]. (2021). URL: https://childdevelop.com.ua/articles/develop/130/ (data zvernennia: 05.05.2021). [in Ukrainian].

Kutsyn, E. K. (2019). Formuvannia osnovy rozvytku osoby stostic zasobamy tvorchoi muzychnoi diialnosti [Formation of basics of development of individuality by means of creative musical activity]. URL: http:// visnyk.chnpu.edu.ua $>$ uploads $>2020 / 05>$ Kutsyn.pdf (data zvernennia: 11.05.2021). [in Ukrainian].

Дата надходження до редакиії: 19.05.2021 p. 